\title{
The Myth of Return: Bosnian Refugees and the Perception of "Home"*
}

\author{
Ondřej ŽílaA \\ Received: May 19, 2015 | Revised: August 10, 2015 | Accepted: September 1, 2015
}

\begin{abstract}
The presented paper deals with the phenomenon of the so-called myth of return in the case of Bosnian refugees and their different perception of "home." The main goal of the paper is to answer the question if it was possible to renew the original concept of "home" in the context of the postwar situation and, more precisely, to delve into the question of how their desire to return "home" (i.e. the so-called myth of return) changed as a result of the prolonging time the refugees lived in a different place. At the same time, the paper analyses the differences in the perception of "home" among the particular constituent nations, explores how members of different age categories differently perceive "home," and last but not least, it focuses on the change of perception of "home" as a result of the social conflict between urban and countryside refugees. The perception of "home" is likewise researched from the point of view of a refugee in a host country, i.e. the role of the diaspora in the return of the refugees is also reflected.
\end{abstract}

Key words: refugees, repatriation, myth of return, perception of home, Bosnia and Herzegovina

\section{Introduction}

Twenty years have passed since the signature of the Dayton peace accords that ended the bloody conflict in Bosnia and Herzegovina (hereafter $\mathrm{BiH}$ ) of 1992-1995. In the period that followed the Dayton agreement, the so-called International Community aimed at reconstructing the ethnically heterogeneous society of Bosnia and at re-building trust and confidence among the local population so necessary for mutual coexistence. As a result of the war, the country was devastated and disorganized and the massive inflow of capital was supposed to create a textbook example of internationally coordinated aid and reconstruction. Even though physical traces of the wartime destruction of Bosnia are disappearing bit by bit, the peacebuilding process, led, controlled, and financed by the International Community, did not manage to remove the actual reasons for which the whole conflict actually broke out. It was neither possible to achieve the main reconstruction goal, i.e. to restore pre-war order and conditions.
The goal of the presented study is not looking into specific ethno-demographic consequences of the socalled forced migrations ${ }^{1}$ in $\mathrm{BiH}$, which took place as a result of the civil war of the 1990s. The article likewise does not address questions such as in what numbers, when and under what conditions Bosniak, Serbian and Croatian refugees headed back to their pre-war homes, nor does it deal with the overall success of the repatriation process. The aim of this paper, in contrast, is primarily to answer the question whether it was at all possible to renew the original concept of "home" in the context of postwar $\mathrm{BiH}$. The study examines what their pre-war home meant to them, how they perceived it from their relocation and how their

\footnotetext{
1 Forced migrations are a general term connected to the movement of all refugees, i. e. of those relocated as a consequence of conflict the same as those relocated because of a natural disaster, chemical or nuclear tragedies, famine, etc. (IASFM 2007). For more information on forced migrations see Harrell-Bond 1988 .
}

\footnotetext{
* The paper is based on the results the research projects supported by the Czech Science Foundation, Grant Project No. P410/10/0136.

A Department of South Slavonic and Balkan Studies, Faculty of Philosophy and Arts, Charles University, Nám. Jana Palacha 2, 116 38 Praha 1, Czech Republic; zila1@seznam.cz
} 
perception of "home" changed due to forced migration and ethnic cleansing. At the same time, the paper aims at determining to what extent it is possible to restore a "home" in its original concept from the outside, i.e. from the status of the International Community and its declared repatriation strategy.

However, it would not be possible to achieve the formulated targets without answering other key questions touching upon the issue, namely: To what extent did the desire of the refugees to return permanently to their prewar home change as a result of the extending period during which they lived in another place (i.e. "the myth of return")? How did the refugee's willingness to return reflect the quality of life in the new environment? Were the refugees indeed willing to return back to their pre-war homes? Last but not least, is it at all possible, given the ambiguous understanding, or more precisely the various culturally conditioned meaning of the word "home," to restore it in $\mathrm{BiH}$ in its original concept?

Bearing the mentioned in mind, the paper analyses the differences in perception of "home" from the point of view of refugees in host countries; it examines the perception of "home" between individual constitutive nations; it investigates the differences in the perception of "home" among the internally displaced persons (IDP) that escaped to larger, or on the contrary to small and medium-size locations; and, finally, it likewise sheds light on how differently "home" was and is perceived depending on the age of the individual in concern. At the same time, the paper does not omit the metamorphosis in the perception of "home" as a consequence of the social conflict taking place between city and countryside refugees. The perception of "home" is likewise outlined from the perspective a refugee in a host country, i.e. the role of the diaspora in the return of the refugees is also reflected.

The primary source base is grounded on field research conducted in $\mathrm{BiH}$ between 2009 and 2013. These investigations took place in the opštinas (municipalities) of Bosanski Petrovac, Čajniče, Donji Vakuf, Drvar, Foča, Glamoć, Han Pijesak, Kalinovik, Konjic, Novi Travnik, Rogatica, Sanski Most, Sokolac, Vlasenica, and Zvornik. The main field research method was based on interviews with local political representatives, organisers of the repatriation of the refugees, administrative workers of particular opština authorities and last but not least with the actors themselves, i.e. with both the refugees and the socalled minority returnees. ${ }^{2}$ As for secondary sources,

2 The so-called minority return represents the repatriation of a refugee who forms the ethnic minority in his place of residence in that particular moment, and that is the case even though before the war he could have belonged among the majority. Repondents in the presented article are marked with an identification number. field research conducted by other authors and other academic literature were likewise taken into account where appropriate.

\section{The International Community ${ }^{3}$ and Its Understanding of the Terms "Return" and "Returnee"}

Ever since the early 1990s, the International Community was convinced that supporting the repatriation of the refugees was a key to successful post-war restoration and reconciliation in the war-torn communities (e.g. Petrin, 2001; Eastmond, 2006). In the Bosnian case, unlike the peaceful solutions to other contemporary military conflicts, the link between successful post-war reconstruction and the return of refugees and their re-integration was particularly tight; the viability of the state system of $\mathrm{BiH}$ could be, according to the West, secured only by strict restoration of the pre-war state of affairs, thus by re-creating a multiethnic society (Stefansson, 2006). The rhetoric of the International Community gave a clear message: If $\mathrm{BiH}$ was to be restored as a "home" for all its inhabitants, these individuals needed to return in the first place to their homeland. In this context, the UNHCR worked out a plan for the repatriation of refugees already in 1996; in it, the concept of "home" simply encompassed the place where the individual had lived before the war broke out (Jansen, 2006). According to estimates, some $90 \%$ of Serbs fled from the Federation of $\mathrm{BiH}$ and up to $95 \%$ of Bosniaks and Croatians were expelled from the area of Republika Srpska in the era under scrutiny (Rosand, 1998).

Hammond notes that the terms "return" and "returnee" embody, at least from the perspective of the International Community, certain encoded value judgements that reflect the established idea of how people should start living again. This idea is based on the assumption that there was a natural bond be-

\footnotetext{
3 Under the umbrella term International Community one can find common action of influential states of the political West (the US, Great Britain, Germany and France in particular) that control international organisational structures (OHR, UNHCR, OBSE, etc.), international military forces and also representatives of influential NGOs. For this reason, the term encompasses all the subjects that have taken and are still taking part in the post-war reconstruction of the country. Jansen considers this term as problematic and overused by Western media. He uses the term Foreign Intervention Agencies (Jansen 2006: 196). Inhabitants of $\mathrm{BiH}$ themselves do not use the term; in the context of the International Community they most commonly use the unofficial term (sometimes highly pejorative) "stranci" (i.e. foreigners). In the presented article, I use the term International Community or its synonyms the West, Western representatives etc. for interventionist Western organisations that lead the reconstruction and still administer (control) the country as such (protectorate).
} 
tween the place and the people who had lived there (Hammond, 1999). In addition, another idea strongly resonated in the approach of the Dayton Agreement authors: If people form a community that derives its identity (except collectively shared culture) also from a particular place, then the actual return of the refugees has to contribute to the restoration of "the natural order of the world." In other words, their return to territories where they had lived before the war (i.e. home) should, by itself, help to calm the ongoing situation and improve the often miserable living standards of the refugees.

The previously mentioned musing was immediately reflected in the central idea of Annex 7 : the fastest possible repatriation of refugees to their homes would contribute to a final settlement of the conflict in Bosnia and Herzegovina (OHR, 1995). From the perspective of the West, this-way-set repatriation policy represented "good" not only for the refugees (guaranteeing them their right to return back home), but also for the governments of states hosting Bosnian refugees (reducing thus the economic burden connected to the matter). Among other things, it was understood as "pure good," simply as the way the world ought to be (Jansen, 2006). In like manner, the International Community also argued that refugees with an unresolved status meant a much greater financial burden for host governments than subsidising their repatriation (Black, 2002). Finally, the declared support of the return on the part of the West, which cannot be monitored in isolation from the pragmatic interests of the US and the most crucial West European governments, likewise accentuated a certain moral attitude, a tendency to remedy the results of ethnic cleansing.

\section{The "Myth of Return"}

Every refugee faced a crucial decision after the peace agreement was signed - whether to return home after all those years spent in a different environment or not. Most of the displaced persons remained quite ambivalent internally. On the one hand was nostalgia, memories and the desire for the landscape of home as they remembered it, and all of these kept sympathies to returning back alive in the places where they had fled to in the time of war. On the other hand, a more pragmatic approach prevailed taking into account both physical and in the case of escaping to the city environment also economic security that only their current place of residence could offer. Nevertheless, they did not give up completely their visions of a possible future return; they continued to live this idea and internally convinced themselves that maybe one day there would indeed be an opportunity for them to return back.

Some authors use the term myth of return in this context. Although the term primarily relates more to the problem of refugees (Kunz, 1998), it is likewise valid for refugees who did not leave the borders of $\mathrm{BiH}$. Within this concept, experts in the field mainly examine the question of whether adaptation and integration in the place of relocation may - in confrontation with the memories of the original "home" - be successful and sustainable in the long run (Jansen, Löfving, 2007).

Zetter, for instance, notes that refugees think of the past, from which they derive their identity, in a highly romanticised way (Zetter, 1999). A refugee, who did not consider returning home as actual and understood it more on the symbolic level (i.e. as an indefinite imaginary desire), made use of it at the same time to idealise his distant future. On the basis of this argument, one can examine the extent to which refugees link their romanticised memories of the past with the view of an imaginary future, perpetuating the "myth of return" alive.

Al-Rasheed adds one more generalising and very important finding for the purposes of this paper. He believes that the intensity of ties and impulses towards the original "home" changes according to the refugee's previous political and socio-economic status (Al-Rasheed, 1991). Conducted field research in $\mathrm{BiH}$ also pointed out a clear trade-off relationship between the refugee's desire to return back and his current socio-economic status and the standard of living in the place of relocation. In general, the higher living standard he or she enjoyed in the new residence, the lower the determination to return was. For this reason, wealthy exiles living in larger urban centres did not consider the return to rural peripheral regions or to smaller and medium-size locations as meaningful.

In his research, Stefansson quoted one of his informants, who himself was socially and economically fully integrated in Sarajevo at the time of the interview - he experienced the politically and economically tense situation in his place of origin, the border town of Trebinje in Republika Srpska. For the man in concern, returning back would be "a crime committed against his own family" (Stefansson, 2004b). On the other hand, during my own field investigation, I noticed that some of the refugees who had survived the war in cities (such as for example Banja Luka), where they had made careers, nevertheless did return to rural remote villages. However, they did not get rid of their assets in the town; on the contrary, they made use of the rent as a complement or even a major source of the family income. ${ }^{4}$

4 Resp. No. 100, born 1948, secondary school education, interview opština Sanski Most 2011; Resp. No. 80, born 1950, secondary school education, interview opština Bosanski Petrovac 2011; Resp.No. 26, born 1943, primary school education, interview opština Foča 2010. 
In like manner, the more the situation in the urban environment was unbearable (if the person was expelled from illegally occupied property, could not get a job, had no connection with relatives abroad, etc.), his desire to return to the rural region increased. Internally displaced persons originally coming from rural areas, who survived in other rural settlements, often resolved to return mainly because the place of relocation did not offer the opportunity to anchor successfully and in an economically advantageous manner. They lived in property that did not belong to them, they tilled only leased land or just cooped without the chance of making a living. ${ }^{5}$

Some informants from the rural municipalities of Han Pijesak, Sokolac, Čajniče, Vlasenica and many more explained their attitude rather succinctly. At the point when they failed to start from scratch in the new location (especially if they did not find a way how to earn a living), they de facto had only two options: either to somehow survive in the local conditions or to simply return back. Yet, this means they had to choose between two similarly poor rural peripheral areas. In cases such as these, the majority decided to return because, if nothing else, they at least had their own house there the same as estate and land to cultivate. ${ }^{6}$

If the previous assertions are connected with AlRasheed's assumptions, one can argue that the idea of the "myth of return" may in some cases rather serve as a convenient tool for political mobilisation. Thus, for example, for the society of Sarajevo the idea of returning back to the place of origin became a political and moral imperative, a means by which it wanted to resist the results of ethnic cleansing and remedy the wrongs of the past (Stefansson, 2004b). In addition, it should be noted that it is precisely this attitude that is fuelled by Sarajevo media and that represents a typical example, which constantly irritates mutual inter-ethnic relations and makes a constructive dialog between Bosniaks and Serbs impossible.

The fact that most Bosniaks from Sarajevo talk about returning, however, in fact do not want to do so, confirms among other things two particular findings. Firstly, property returned to the Bosniaks often served as a convenient source to finance the purchase of housing units in their new home, for example in Sarajevo. Secondly, conducted field research in areas

5 Resp. No. 45, born 1939, primary school education, interview opština Donji Vakuf 2010;Rresp. No. 71, born 1950, primary school education, interview opština Zvornik 2011.

6 Resp. No. 1, born 1960, primary school education, interview opština Čajniće 2009; Resp. No. 13, born 1963, primary school education, interview opština Han Pijesak 2009; Resp. No. 52, born 1954, primary school education, interview opština Vlasenica 2011. from which the Bosniaks escaped to Sarajevo (Foca, Kalinovik, Sokolac, etc.) demonstrably confirms their unwillingness to return to their original homes. The most common answer to the question why the refugees were unwilling to return was "there is no future" ("nema perspektive"). ${ }^{7}$ Nonetheless, the state of affairs does not prevent the Bosniaks to keep their former homes (if they had not been sold) as weekend houses (so-called vikendice).

The myth of returning home was also deeply politicized in diaspora communities (Perica, 2009, 2011; about political mythology of diaspora see below in the text). The concept of the "myth or return," however, does not have to be strictly valid in all cases. Unrestrained socio-economic and interrelated ethno-demographic changes that sparked the intensive population shifts after the Second World War meant that a significant proportion of people found a "home" elsewhere than they had been born even before the civil war (Žíla, 2013).

\section{The Cultural Significance of "Home" in Former Yugoslavia}

Although the number of urban dwellers in socialist $\mathrm{BiH}$ more than doubled between 1948 and 1991, most people $(61 \%)$ still remained in the countryside (Markotić, 1996). This trend replicated the whole-Yugoslav model even though with considerable delays. It is possible to observe the same intention, i.e. the effort to secure adequate housing, in rural and small-town populations of Federal Yugoslavia. A house formed the central point around which rural households of former Yugoslavia revolved, where saved funds were invested, it was likewise the place of family life and represented the social status of families and their cultural values.

After the Second World War, the majority of the population in rural areas of $\mathrm{BiH}$ still lived in patrilineal widely branched families. Only in the course of socialist modernisation, individual households, in which even other relatives of the husband's relational line were involved, began to adapt to the Europeantype nuclear family. This transition took place much faster in larger cities, where the society's elites were already fully entrenched and fully satisfied having their own apartment.

The Norwegian anthropologist Tone Bringa notes that building a house was a lifelong project for the majority of the local population. Men and women worked hard for years to fulfil their life's desire to have a house of their own. Constructing their homes, which could

\footnotetext{
Resp. No. 59, born 1945, secondary school education, interview opština Kalinovik 2011; Resp. No. 92, born 1953, primary school education, interview opština Sokolac 2011.
} 
take more than a few decades, was often financed by money they had earned while working abroad. A successful completion of the construction, among other things, symbolised for the man, husband and father the confirmation of his social and material status within the local community (Bringa, 2009).

Another reason why having a house was so important in rural society may lie in the situation that occurred with the change of ownership after 1945. Until then, the private farmer usually imposed any saved capital into the soil in order to expand his land ownership (Jelavich, 1983). Despite the fact that attempts of the Yugoslav Communists to collectivise the countryside failed, the villagers were allowed to own only a limited area of land. For this reason they even more clamped to the construction, expansion and rebuilding of their property that formed the central location where the accumulated funds were stored.

Only when one realises how long and with what care the house was built and the symbolic meaning it had for the rural population, one can understand the tragedy of the systematic burning of houses during the civil war and the disastrous consequences for their inhabitants (Bringa, 2009). One should keep in mind that for each of the tens of thousands of Bosnian ruins stands a destroyed and wasted lifelong project and efforts of individuals (Stefansson, 2004). The warring parties moved ahead with the intention to once and for all put an end to the physical presence of the ethnic minority. This corresponded with a well-thoughtout and thorough destruction that was to prevent any possible recovery. It was not only about the mere expulsion of civilians, but also about creating such an atmosphere of fear that would discourage persons potentially interested in returning back.

\section{The Willingness of the Refugee to Return as a Result of a Different Perception of Home ${ }^{8}$}

Of course, there is not one single universally valid answer or definition to the question what "home" is. The term has a different meaning for different people. Indeed, the definition of "home" is a very complex and a very personal matter. Academic literature on repatriation policy (i.e. the actual process of returning "home") likewise examines the various examples and nuances of the concept of "home" (Black, 2002; Bringa, 2009). If one understands the terms "return" and "returnee" as interpreted by the International Community, i.e. in the sense of a real return to the former residence, the place where the refugee had lived before the war ("home"), then in the case of repatriation

8 This study focuses primarily on the term "home." Particular individual objective and subjective obstacles the person willing to return had to face are not explicitly researched. of not only the internally displaced persons, but also in the case of refugees from third countries, there is a fundamental conceptual problem. Repatriation of refugees cannot be identified with returning "home" (and thus restoring the natural order, the previous conditions respectively) if the individual constitutive peoples approach the two differing terms "home" and "homeland" differently, and if "home" was not created within the entire territory of $\mathrm{BiH}$. At this point, therefore, one faces a different perception of "home" among individual ethnicities or, to be more precise, the differences in conceptualisation of the two terms a broader and narrower idea of home, i.e. "home" and "homeland"(Jansen, 2006).

Serbian and Croatian politicians advanced, especially at the beginning of the conflict, in such a manner so that the territories they controlled would become an integral part of broader national units, which represented the neighbouring "mother" states (i.e. Croatia and Serbia, the Federal Republic of Yugoslavia respectively). However, because of the pressure the war development brought about they had to modify their attitudes; towards the end of the war, they tried to secure control at least over smaller, ethnically pure territories where they dominated at that particular moment. In this context, the concept of home meant living among members of one's nation on one ethnically cleansed territory of their own (Jansen, 2006). Nevertheless, they continued to see the broader term "homeland" in the neighbouring mother republics.

The Serbian population of $\mathrm{BiH}$ does not perceive a fundamental semantic difference between the Republika Srpska and Serbia, and the Bosnian Croatians hold a similar position in their case. In other words, both the Croats and the Serbs of Bosnia and Herzegovina see themselves as a part of wider Serbian and Croatians societies. Serbian political leaders view the ethnic line defined by Dayton as a border of a "higher order" in comparison with the boundaries between the Republika Srpska and Serbia on the Drina River. In like manner, Croats, especially those from Herzegovina, consider the border between Bosnia and Herzegovina and Croatia more as an administrative boundary rather than a de facto state border. ${ }^{9}$

The Muslim discourse, furthermore, is a much more complicated and complex problem. Bosniaks, who have no physical connection with a neighbouring "mother" country, consider the whole territory of $\mathrm{BiH}$ as their "homeland." Of all the three ethnic groups they identified themselves the most with the territory under scrutiny (O'Loughlin, 2010). The Bosniak elites therefore also supported more intensively

\footnotetext{
9 Almost all Serbian and Croatian respondents expressed such a perception.
} 
both politically and economically the return of Muslim refugees to their pre-war homes when compared to their Serbian and Croatian counterparts. This attitude, which exactly copied the repatriation strategy declared by the West, constituted a key answer to the question why Muslim refugees returned to their original residence in higher numbers compared to the other two nations.

On the other hand, a positive attitude towards their own repatriation by no means meant tolerating or perhaps even supporting the minority return of nonBosniak refugees to the areas in concern. Members of the Bosniak political elite, the same as their Serbian and Croatian counterparts, fiercely resisted minority repatriation.

Refugees who did not think about an immediate return tried to build at least the basics of a "normal life" in their new settlement. By doing so, they primarily relied on two key elements: the efforts to earn a livelihood and to integrate into local society (Stefansson, 2004a). The longer time they spent in the new settlement and the more they got accustomed with the local environment, the more their understanding of "home" gradually changed; the resettled person bit by bit identified him-/herself with the new surroundings and a temporary residence became a permanent address (a new "home"). As for successful restitution, by the end of 2005, the UNHCR reported, based on information received from the municipalities, that $99 \%$ of requests for restitution were successfully resolved (MHRR, 2010); however, this did not changed anything in his or her attitude. In fact, the claimant did not seek to restore the "home" in its original extent.

\section{The Perception of "Home" from the Point of View of a Refugee in the Host Country and the Role of the Diaspora ${ }^{10}$ upon Return}

The topic of the diaspora and return to one's homeland is a well-known motif of the post-socialist and postwar discourse in the territory of the former Yugoslavia. The diaspora myth plays a special role among constitutional national myths of post-Yugoslav nations (Bošković, Gavrilović, Perica, 2011). Throughout the 1990s the diaspora issue was discussed frequently and diaspora communities were used in new political discourse; the diasporic community became political active and began participating in mass mobilization of ethnic movements. In the 1991-1995 wars, the ethno-diaspora was an active participant and relevant factor in the conflict (Perica, 2011). My aim in this study is not to focus on political mythology of diaspora in-depth, neither to analyse its massive political

10 The term diaspora is used only in relation to Bosnian refugees in this text. and socio-economic influence in Bosnia and Herzegovina or more generally in ex-Yugoslav states (Perica, 2009, 2011; Hockenos, 2003; Valenta, Ramet, 2011). What follows instead is mainly concerned with the perception of "home" from the point of view of resettled people originally from Bosnia and Herzegovina.

In connection with the Bosnian refugees who significantly broaden diaspora community in 1990s, one can observe a rather strange paradox. While a large proportion of them (especially within the first generation) expressed their willingness to return home (i.e. the myth of return resonated very strong among them), and host countries took part in various repatriation programmes, only a very few refugees eventually made their proclaimed determination become reality and returned permanently to $\mathrm{BiH}$. Even though the aim of the presented paper is not to analyse the behaviour of the Bosnian refugee community in host countries, it is necessary, at least in a few words, to deal with the role the diaspora played in the process under scrutiny and the willingness of Bosnians to return in the first place.

A diaspora can be defined as a group of transnational migrants living in host countries whose economic, political, social and emotional ties remain connected with their mother country (Faist, 2000). However, this generalising definition ignores the very specific form of forced migration, which led thousands of refugees abroad in the analysed matter. In the case of their arrival in a host country, one cannot speak of a transnational identity in the early years of their stay (Kovačević, 2013; Coughlan, Owens-Manley, 2006). At the same time, research devoted to the Bosnian diaspora shows it is not clear to what extent refugees residing in a host country truly longed for their return to $\mathrm{BiH}$, to what extent their willingness to return home diminished after a certain period of time and at what point their tendency to assimilate started to predominate (Raduški, 2011; Eastmond, 1998; Hasić, 2004; Huttunen, 2005; Stefansson, 2006; Al-Ali, 2001). Some political analysts, Tigran Hasić among them, consider Bosnian refugees living in host countries with an unsolved status as part of so-called "limbo diaspora." These were people who for various reasons failed to fully integrate into the host country environment, adopt to their new settlement, to understand it as their new "home," who understood their stay in the host country as only temporary and maintained close links with their country of origin (Hasić, 2004). The social anthropologist of the name Laura Huttunen noticed a similar fluctuation among Bosnian refugees in Finland when it comes to the question what actually "home" represented for these refugees at the time when she was looking into the matter. Because of a certain embarrassment and unease the 
refugees approached both their country of origin and the asylum country, she labelled the community with the term "hesitant diaspora" (Huttunen, 2005). In a situation in which refugees simultaneously build a "new life" outside $\mathrm{BiH}$ and simultaneously leave the possibility to return open, the sense of "home" takes on a whole new dimension. Sociologist Nadja Al-Ali observes, based on her research on Bosnian refugees conducted in Great Britain and the Netherlands, that the refugees rather than living a "double life" found themselves in many cases in an unclear situation between two possibilities: Bosnian refugees did not feel "at home" neither in the host country nor in the country of their origin (Al-Ali, 2001).

Nevertheless, keeping all this in mind, one can conclude that homesickness among the refugees in the host countries was encourage by specific factors that resettled persons in $\mathrm{BiH}$ and refugees residing in other former Yugoslav republics did not face to such an extent. Willingness to try to return back to $\mathrm{BiH}$ was strengthened especially by the inability to fully integrate into the environment of the host country, by the language barrier, cultural differences, non-recognition on the part of the majority (foreign) societies as well as the refugee community itself, and by high unemployment rates. Many of the asylum seekers increasingly dipped into deeper and deeper apathy and discontent because of their dependence on social welfare, the inability to find employment, prohibition of work or the possibility of performing only menial jobs and tasks (Al-Ali, 2002). On the contrary, persistent threat of socio-economic marginalisation in their host country and the improving security situation in $\mathrm{BiH}$ after the end of the war increased the commitment of these people to return (Eastmond, 1998).

The Bosnian diaspora, despite its not exactly clear position, played and even still plays a key role in helping relatives in $\mathrm{BiH}$. Bosnian refugees who permanently settled in host countries intensively helped those interested in return both during the repatriation procedure itself and after the actual return to their homeland (Jakobsen, 2011). Contacts and links in widely extended families were of great significance already in former Yugoslavia. Bonding to more distant relatives remained very strong also in the final years of socialist Yugoslavia even though in agrarian areas the nuclear type of family started to prevail (Bringa, 2009; Marković, 2005). The significance of relatives and their relations, based on mutual trust and help, grew even more during the civil war during which neighbourly ties were disrupted and the untilthen effectively functioning social networks were severed. For this reason, family ties became more important again because of the absence of another form of social capital (Al-Ali, 2002). At the same time, refu- gees living in host countries who successfully adapted themselves to the new environment felt a specific bond to their wider family living in $\mathrm{BiH}$ who often faced a miserable existence in extremely inhospitable conditions.

The living standards of the vast majority (especially ethnic minority) repatriates was therefore at the point of return dependent to a certain extent on the intensity of the family ties the returnees had with the "outside world" (i.e. with relatives living in diaspora or in bigger cities and towns in $\mathrm{BiH}$ ) and their financial support. Relatives who send money (in average as much as $200 \mathrm{KM}$ per month) (UNDP, 2002) to their relatives in $\mathrm{BiH}$ to live on de facto substitute the non-functioning the social system of the country. The sent amount forms, in comparison with social benefits, the biggest and most regular form of support of existence of the returnees (Kostić, 2003). Minority repatriates without financial support from the outside lived a miserable existence on the edges of society and became the most vulnerable category in society (Žila, 2014). This dependence on finances of the diaspora means that a permanent (sustainable) return of refugees is largely closely linked with those who put down roots in a new "home," i.e. somewhere else in $\mathrm{BiH}$ or abroad (Stefansson, 2006).

At the same time, efforts to financially and materially arrange for the family often led to postponing the final decision of the refugees to return back. Many parents-refugees waited with the their return until their children were able to stand on their own feet in the host country, i.e. mainly until they completed their education, reached legal age, found a well-paid job and so on. Only at the moment when the children were provided for (or at least when they had the feeling this is the case), they were willing to return back to $\mathrm{BiH} .{ }^{11}$

Relying on financial help from abroad that would ensure the returnee's survival was actually a continuation of the gastarbeiter tradition inherited from the period of socialist Yugoslavia (Kovačević, Krstić, 2011; Marković, 2009; Grčić, 1990). The significant (and maybe even still growing) strength of the Bosnian diaspora as a consequence of the difficult economic situation in $\mathrm{BiH}$ likewise shows how important the refugee community is and what role it plays in the post-Dayton system. Relatives living abroad can offer not only material help, they can also provide assistance to those who want to leave the country (form example in the form of requesting the unification of the family) (Huttunen, 2005). For a part of the Bos-

11 For example Resp. No. 188, born 1953, tertiary education, interview opština Olovo 2011; Resp. 195, born 1961, primary school education, interview opština Dobretići 2011; Resp. 197, born 1959, secondary school education,interview opština Vareš 2011. 
nian population the choice of emigration is crucial and some of them can actually carry it out because of family relations. This represents the last option for them and their closest relatives to ensure a better life.

On the other hand, however, not every returnee or the IDP can, of course, rely on the help of his offspring and his extended family living abroad. In those cases the willingness to return back to their pre-war home would come to no avail if the person in concern did not receive financial support on the part of the governments willing to accept Bosnian refugees during the conflict. Without funds, the refugees would return and re-new their dwellings only very difficultly.

The refugees who settled in the former Yugoslav republics showed much less willingness to eventually return back to $\mathrm{BiH}$ in the future. In the vast majority, these were persons of Serbian and Croatian nationality who managed to integrate more successfully than refugees in West European countries. Only some seniors remained unsure when it came to the question of repatriation (Lukić, Nikitović, 2004; Lukić, 2005). This stance was not even changed by the fact that even they themselves engaged to a certain extent in the repatriation process (most of them at least requested the return of their property) (Jansen, 2005).

\section{The Perception of "Home" of Internally Displaced Persons in Middle-Size and Small Settlements}

The way the displaced persons of all nationalities who settled in middle-size and small urban settlements understood the question of "home" is much more difficult to detect. In this case, one cannot find a certain unifying and generally valid formula in the framework of the "myth or return"; it always depends on the stance of the individual, the intensity of his or her own desire to return and on the place of origin within $\mathrm{BiH}$ of the person in concern. In general, one can argue that the probability of return decreased as a result of "typical obstacles" and, on top of that, with the worsening availability and accessibility of the settlement (greater distance from the regional centre, the quality of infrastructure), the growing level of its periphery or unfavourable natural conditions for agriculture (less fertile lands in mountain areas). The last mentioned factor plays a role in the difference of intensity of the return between fertile countryside areas (e.g. the Sava region) and rural regions where agriculture conditions are often very limited (Herzegovina, the Drina region, etc.).

It is even more difficult to evaluate the qualitative differences in the success of minority return to the urban and countryside environment. When looking at the effectivity of long-term sustainability of minority return it is not possible to bear majority conclusions from other countries of Central and Western
Europe. The assumption that better living conditions (in the form greater possibilities of work for example) prevailing in the urban environment did not necessary mean that the Bosnian-Herzegovinian inhabitants would more intensively return to cities and towns.

In the post-war development of $\mathrm{BiH}$, as a result of the war destruction and unsuccessful economic transformation, a political, economic and social crisis is still taking place. In fact, the crisis is getting even tougher. The official unemployment rate reached the incredible figure of $42.4 \%$ in 2011 (BHAS, 2011). Middle-size and small cities and towns, where narrowly specialised production prevailed before the war, suffered most when it came to the consequences of the unsatisfactory transformation of the economic system (i.e. the fall of industrial production) and extremely unsuccessful privatisation. In all the visited previously middle-size developed cities (e.g. Donji Vakuf, Foča, Zvornik, Drvar, Bosanski Petrovac, Glamoć, Novi Travnik, etc.) industrial production reached the maximum of $5 \%$ of its pre-war level. In addition, the absolute majority of privatised manufacturing companies went bankrupt. $^{12}$

The refugees, of course, took economic calculations into account when thinking about returning and help to explain why they returned more to villages than to cities and towns (ICG, 2002). At the same time, however, one should emphasise that in this case, they returned to more fertile agrarian areas intensively farmed and linked to bigger urban centres both in terms of economy and transport. "Home" in the countryside, in contrast to the urban environment where the entire industrial sector collapsed, allowed the unemployed returnee who owned a cow or several sheep for example in combination with a meagre pension, other social allowances or with the help or relatives abroad to at least partially to survive from his or her own resources.

Yet, there is no need to emphasise too much that most of the repatriates linked their life with the urban environment. Another somewhat underestimated factor of the change of the perception of "home" contributed to preferring the urban way of life. This factor likewise was associated with the economic and political transition, its economic consequences and the breakup of the single Yugoslav economic market. Not all countryside inhabitants in socialist Yugoslavia, especially from those countryside settlements that were located in the hinterland of middle-size and bigger cities, lived only on the agricultural sector. Agriculture, then, in many cases served only as a supplement

12 Resp. No. 41, born 1956, tertiary education, interview opština Donji Vakuf 2011; Rresp. No. 121, born 1960, tertiary education, interview opština Novi Travnik 2011; Resp. No. 130, born 1963, tertiary education, interview opština Glamoć 2011. 
to regular employment in the secondary or tertiary sector. For this reason, the vast majority of countryside settlements in socialist $\mathrm{BiH}$ was interconnected with cities and towns in terms of infrastructure and a regular bus line existed in most of them with buses going back and forth even a few times per day. The decision to stay in the city into which the family moved during the war or to settle close to it meant a logical outcome of the pre-war inclination to the city.

\section{Permanently Uninhabited (Empty), However Looked after Property}

The "myth of return" likewise to a certain extent contributed to the fact that the refugees did not want to get rid of their original dwelling. Indeed, nostalgia, unwillingness to give up something they had built and taken care of for many years prevented them from selling or exchanging the property. They still cared about the property they gained back in the restitution process and this was the case even though they had no intention to return back permanently. Most commonly, they made an agreement with one of the local former neighbours who, in return for looking after and taking care of their house, for instance, had the possibility to make use of their land, for example. Such cooperation sometimes even took the form of specific "employment" when the former komšija, often himself unemployed, grazed livestock, functioned as an agricultural supplier, house manager or watchman. In such a situation, close and bosom neighbourly relations typical not only for the Bosnian environment of socialist Yugoslavia functioned very well. ${ }^{13}$

An important precondition for a more intensified form of cooperation was geographical proximity and accessibility (the quality of infrastructure) of the new and original residence. Many Serbs living in Vlasenica (RS) have their estates in the neighbouring city of Kladajn (Federation $\mathrm{BiH}$ ) managed by locals and regularly (most commonly once a week on average) visit it. An interesting fact came out of the debates and that is that the majority of them ds not stay overnight and after inspection and a short rest head back to Vlasenica. ${ }^{14}$ On the other hand, such a form of cooperation (management) can be found even in village opštinas of Foča, Han Pijesak and more located quite far away from Sarajevo. ${ }^{15}$ The new Sarajevo elite, originally

13 Resp. No. 107, born 1942, primary school education, interview opština Sanski Most 2011; Resp. No. 40, born 1960, primary school education, interview opština Donji Vakuf 2011.

14 Resp. No. 109, born 1952, secondary school education, interview opština Vlasenica 2011; Resp. No. 115, born 1963, secondary school education, interview opština Vlasenica 2011.

15 Resp. No. 23, born 1975, primary school education, interview opština Foča 2010; Resp. No. 29, born 1964, primary school education, interview opština Foča 2010; Resp. No. 18, born 1971, primary school education, interview opština Han Pijesak 2009. coming from these regions, reconstructed their property and used them for recreation. Persons belonging to the same nations, who returned after the war, were responsible for maintenance of the property in concern. On the initiative of the owners, village roads were often repaired, local sacral objects (mosques) were renewed and the overall character of the village was restored in order to match as closely as possible the pre-war appearance.

In the largest Bosnian cities (Sarajevo, Banja, Luka, Mostar, Tuzla, etc.) it is possible to observe the phenomenon of tens of empty houses even in the most lucrative areas; obviously, nobody lives in them. Many of them were repaired and renovated by their owners, others are dilapidated and because of their condition can only hardly be repaired. The absent owners refused to sell the houses, sometimes they even refused to let them, because of a mixture of nostalgia, emotional links, pragmatism or even indifference.

Such a stance is most typical for Bosniaks coming from Banja Luka. In contrast, a much more "economic" approach to their pre-war property was adopted by Serbs who left Sarajevo during or shortly after the war. The majority of them sold their flats and houses, or at least commercially let them during the first possible occasion. The ruined houses that even today disfigure many of the urban centres (for example the centre of the city of Jajka); however, without the permission of the owner, one can hardly do nothing about it. The owner of the destroyed property (and its associated land) who often lives abroad or is fully saturated in one of the big cities of $\mathrm{BiH}$ had and has no interest in reconstruction or sale. They usually wait with selling their property while for the price to increase as a consequence of the attractiveness of the location. The native home gives the refugees the possibility to return for good in the future (for example in their retirement). On top of moral and pragmatic reasons why property owners refuse to let the house, one could find certain fears that Serbs would devastate their regained property (Stefansson, 2006).

\section{The Perception of "Home" among Particular Age Categories}

Another factor that influences return is the demographic structure of the repatriates. The strongest desire for the pre-war home can be found among the older generation of repatriates. These people lived their whole life in the place of their origin and indeed wanted to spend the rest of there as well. Seniors that returned to the countryside answered the question of why they had decided to return back in the following manner: "because this is my home," "this is the place where I was born and it is the place where I want 
to be buried."16 Some pensioners did not even understand the question, did not understand why somebody would asked them something that was so obvious. ${ }^{17}$

More conservative individuals who lived in a traditional way until the outbreak of the war expressed their willingness to return in the manner that they were used to the circle of life connected to the agricultural year cycle. In the period when they resettled and were squeezed inside urban centres, had no land of their own and therefore possessed no opportunity for their own livelihood, then they longed for the moment when they could return. They perceived their expulsion and forced re-settlement to the collective centre or following their relatives into the city in a rather painful manner. Living in a city was not their free choice, it was destitution in the name of salvation before the moving war front. They refused to adopt to the foreign environment and grievously handled their unsettled situation, they did not feel well here and longed for a definitive settlement of all the uncertainties that their refugee status brought about. Returning, despite of all the existential problems resulting from it, meant nevertheless a certain calming of the situation and at least a partial renewal of certainties. The moment when the returnee collected the keys from his house was valued as one of the most beautiful moments of his or her life. The key represented the symbol that the rightful owner of the house was not a disposed refugee anymore (Stefansson, 2006).

Indeed, it was the desire of older people to return to the traditional way of life and also, for example, fears of the possible missing of the next crops that played a decisive role in the initial de facto zero minority return in the region of South-East Republika Srpska for instance. After the year 2000, the first groups of repatriates crossed the entity border and headed to villages in the opštinas of Foča, Čajniče, Gacko, etc. (Fischel De Andrade, Delaney, 2001). Right after their return, the repatriates had to take care of the land itself, of sowing and therefore of livelihood. The question where to sleep was only secondary. This type of "spontaneous" return was accompanied by an improvised construction of tented settlements. Only from a certain time distance did the returnees renew and restore their homes with the help and financial assistance of reconstruction programmes (O'Onofrio, 2004).

Middle-aged persons had bigger problems to adapt themselves to the new environment and, consequent-

16 Resp. No. 4, born 1940,primary school education, interview opština Čajniće 2009; Resp. No. 21, born 1944, primary school education, interview opština Foča 2010; Resp. No. 64, born 1952, primary school education, interview opština Kalinovik 2011

17 Resp. No. 19, born 1938, primary school education, interview opština Foča 2010; Resp. No. 132, born 1937, primary school education, interview opština Glamoć 2011. ly, they belonged to the category of those potentially interested in returning back. They often joined the spontaneously returning people. This age category likewise initially bore their new position with great displeasure. A pragmatic evaluation of the advantages of the urban environment prevailed only over a certain period of time: better living conditions in general and security in particular that the returnees who not able to find, at least at the beginning, in the rural areas. Members of this group, who successfully adapted themselves to the new environment, i.e. the cities and towns, maintain the most intensive contact with the former residence. They either visit their parents who had returned back or they go there in their free time in order to relax. ${ }^{18}$

On the contrary, younger generations of refugees, children born during the war, do not feel a strong bond to the place of birth of their parents. In the majority of cases they grew up in urban zones, collective centres outside rural areas, where they likewise received their education. Because of their age, they experienced no problems while adapting and socially integrating into urban society. These individuals, the same as those who in the time of industrialisation of socialist Yugoslavia commuted for education and work into cities and towns, had the possibility to return to their initial roots, i.e. back to the countryside, often peripheral regions where the only means of livelihood was agriculture. Even though a good number of them remained unemployed, they did not consider the alternative of returning to the countryside areas of their parents and grandparents; they were virtually swallowed by the urban way of life. Among other things, a significant proportion of younger persons $(67 \%$ persons in the age between 18 and 35 ) expressed their willingness to leave $\mathrm{BiH}$ once and for all (UNDP, 2010).

\section{Forced Urbanisation: The Perception of "Home" through the Lenses of Social Conflict of the Urban and Countryside Refugee}

The ethnic conflict, as a result of which more than half of the population of $\mathrm{BiH}$ ran away from their homes, caused the reorganisation of the country along ethnic lines. On its basis, the ordinary Bosnian-Herzegovinian inhabitant perceives his everyday life in the post-Dayton period exclusively through the prism of his own ethnicity. This way of thinking that penetrates all spheres of life demonstrates to what extent did political propaganda, violence committed during the conflict, post-war discrimination and even the unsufficient ensuring of safety influence the thinking

18 Resp. No. 38, born 1965, secondary school education, interview opština Foča 2010; Resp. No. 139, born 1966, secondary school education, interview opština Rogatica 2011. 
of one nation about the other or, to be more precise, to what extent thinking of people generally monopolised the omnipresent emphasis on ethnicity (Kolind, 2003). Minority repatriates, as the representatives of the "enemy" nation, were more than once received in a negative manner upon return and, moreover, they were likewise often considered within the framework of ethnic categorisation as the originators of all the problems that resulted from the conflict.

A more detailed analysis based on field research, however, suggests that the society of Bosnia and Herzegovina is not divided only along ethnic lines, but also according to their social origin. In other words, the strict emphasis on ethnic categorisation did not have to play the primary role in all cases; in the urban environment, the problem of socially maladjusted of the coming countrymen of the same nationality and distaste for their different behaviour on the part of the urban, educated and culturally more advanced old residents often drown out the issue of ethnic categorisation.

Society of Bosnia and Herzegovina (and even of the whole of Yugoslavia) was characterised by a sharp divide between the urban and the countryside environment already before the escalation of the conflict in the 199os. Yugoslav leadership right after the Second World War acceded to measures in order to modernise and make effective the cumbersome economic and social system. Modernising social transformations in $\mathrm{BiH}$, especially if one takes into account the initial conditions (i.e. the fact of a still traditional agrarian society after the Second World War), were indeed radical. Many innovative features and elements were to be seen in the steadily expanding urbanisation process in the most strident manner. However, despite the obvious intensity and dynamics of accepting the urban way of life, it took the peasants, who more and more often commuted to urban centres for work, still a long time before they settled in the cities and towns permanently. The physical transfer of population from the agrarian countryside environment into cities and towns took even more than one or two decades. The civil war that broke out as a result of the disintegration of federative Yugoslavia had an impact on the until-then gradually advancing urbanisation trend as as "social accelerator" (Belloni, 2007). Due to the nature of the conflict, i.e. the efforts of ethnic homogenisation of the area, the character of the geographic spreading of the population changed radically, the say the least. The collective stampede from the rural areas was accompanied, at the same time, by intensive urbanisation. Whole families found themselves within collective centres in cities and towns as they basted ethnically cleansed regions (Ó Tuathail, Dahlman, 2004).
Simultaneous movements of migrants gradually homogenised communities in both the cities and towns and in the countryside; yet, at the same time, they blended in terms of socio-cultural aspects (Hallergård, 1999). The Serbians from Sarajevo headed, among other places, also to the rural regions of Republika Srpska (into the hinterland of Bijeljina, Višegrad, Zvornik); the Bosniak population, on the contrary, moved into the Sarajevo basin in droves. Both of these forced migration flows were accompanied by arbitrary occupation of somebody else's property.

The refugees had to adapt to conditions in for them until-then unknown environments (urban vs countryside). The adaptation of countrymen who escaped to cities and towns was rather difficult not only for them, but also for the indigenous local people. Autochtons who were under pressure because of the influx of the villagers accepted the changing face of the city with great displeasure. The social conflict resonated between culturally rather different residents who, because of the circumstances and against their will, had to share common space (Cattaruzza, 2001).

The ferocity and intensity of forced migration resulted in an unprecedented confrontation of disposed people of the same nation. These people driven away from their cultural environment found themselves from the economic point of view outside their natural habitat of earnings. Their experiences and skills could not be developed or even utilised in their new settlement (Hallergård, 1999).

Acrimonious disputes between the two cultural forms, which lived apart and relatively separately for decades, took the shape of a latent conflict. Obvious differences in customs, clothing and behaviour between the urban and rural population, both of which found themselves in the same area as a result of the conflict, represented a permanent source of tension and animosity. The Sarajevans, for instance, labelled the incoming countrymen as primitivci, or even more pejoratively as papci (papak in the singular form), thus literally lubbers and klutzes.

The original inhabitants of the city approached the newcomers, who destroyed historical monuments and did not adhere to the same values of life as them, with numerous prejudices. Journalist Joe Sacco, for instance, in his reportage comics, recorded the hardships of Bosniak residents in the besieged enclave of Gorazde; in the conclusion, he aptly portrayed the feeling of the there-settled Sarajevans. The phrase "Sarajevo was full of Gorazde" succinctly expressed the post-war situation, where the original Sarajevans did not find their friends while walking around the city centre of Ferhadija and Baščaršija, but met foreign suspiciously- and rustic-looking new inhabitants of the Sarajevo metropolis. 
For the newcomers, Sarajevo, despite the degree of damage and shabbiness, seemed like a city full of life and opportunities (Sacco, 2007). Newcomers from the countryside were socially stigmatised and, like the minority returnees, were considered to be persons belonging to the second category of citizens. They were fully aware of their status of the uncared-for, the abandoned, which they likewise associated with homelessness. For this reason, they tried to act as the "locals" or "migrants" seeking employment or education rather than as Internally Displaced Persons (Stefansson, 2004).

Socio-cultural tensions in Sarajevo and Banja Luka augmented also by the question whether the immigrants were actually able to successfully adapt to the city conditions the same as the concern whether the city would not, in the case of failure of re-integration, become fragmented into small and mutually weakly interconnected parts. In fact, such a situation did indeed de facto occur in both of the cities under scrutiny - although not always on the basis of socio-cultural differences, but also due to certain minority repatriation. Some parts of Sarajevo and Banja Luka, located on the fringe of the two cities, live a life of their own, which is not gradient with the urban centre. On top of that, the social conflict in the case of Sarajevo is further enriched with one more aspect, i.e. the arrival of the Muslim population of the neighbouring region of Sandzak, which lies on the border between Serbia and Montenegro. Muslims, who intensively headed from Sandzak and other towns with a majority Bosniak population, pursued a completely different behavioural pattern than what Sarajevans had been used to in the case of rural Muslim newcomers.

In addition to problematic coexistence of villagers who arrived in the city, one can only hardly imagine what the urban population went through after their escape from cities to the rural regions. One can argue that especially Serbs from Sarajevo must have accustomed themselves in a rather difficult manner to their new settlements in the regions of Zvornik, Višegrad, Bijeljina and others. Their motives, feelings and opinions the same the course of their departure itself had not been researched. The same can be said about monitoring the progress of their adaptation, difficulties and psychological issues these people from urban centres experienced and had to cope with in the rural regions. Cultural habits and a wider range of employment options of the largest Bosnian city were drastically confronted with the dire situation in the peripheral regions of the inhospitable Eastern part of the Republika Srpska.

Escaped urban residents often explained the occupation of their homes as a certain kind of envy. Villagers often felt that life in the city seemed as a facilita- tion and relief in their previous existence. For example, some of the Bosniaks from Stolec explained the seizure of their houses by Croatians from rural, very inhospitable surrounding areas in such a manner. Other residents who were forced to run away from cities approached the matter in a similar way (Kolind, 2003). In addition, the urban way of life symbolised even the fulfilment of their lifelong dream of leaving for a more convenient environment, which they failed (and were not even able to) make reality before. The moment when the hostilities were initiated became the appropriate opportunity to do so. One can add, however, that there were also villagers who fled into cities and towns under the pressure of wartime events and were much displeased about it. These displaced persons understood and perceived their placement in the city, something they did not desire in the least as the environment remained alien to them, only as something temporarily.

Obvious social and cultural differences that resulted from violent urbanisation even downed manifestations of ethnic stigmatisation. The population, though it identified itself on the basis of ethnicity, strictly distinguished who came from what cultural background. In the aforementioned municipality of Stolac, local Bosniaks differentiated between Croats from rural areas, newcomers to the city of Stolac and Croats who had lived in the city before the war. Bosniaks labelled the lastly mentioned group as pravi stolčani, i.e. the true dwellers of the city of the city of Stolec, against whom they had no negative prejudices (Kolind, 2003).

As a result of social tensions among the urban population, originating from culturally diverse environments, one can also observe even some attempts at ethnic reconciliation. Eastmond, for instance, recorded the experience of one Bosniak couple who renewed their home in Banja Luka. Their Serbian neighbour expressed genuine joy over their return or, to be more precise, he rejoiced over the fact that he finally had back his "civilised" neighbours (i.e. members of the urban middle class to which he himself belonged), and got rid of displaced Serbians from rural areas who lived in the house in their absence and who had a different lifestyle that extremely did not suit him (Eastmond, 2006). Ó Tuathail with Dahlman show another example, this time from Derwent, where local Serbs complained about the Serbian newcomers as neighbours and positively thought of their former Croatian and Muslim neighbours (Ó Tuathail, Dahlman, 2005).

In addition to different modes of behaviour, the new rural population often brought along crime and radicalism (Stefansson, 2006). Nationalist parties skilfully made use and exploited the frustrated masses of dispossessed peasants even after the end of the conflict as they were natural and easy targets for their 
ongoing mobilisation campaign. Less educated classes, of course, echoed most to the populist slogans of the nationalists aimed at strengthening their position.

Neither the quick remedy of the physical consequences of the war, i.e. damaged buildings and infrastructure, could not erase the traces of the conflict. Social tensions between the old residents, who perceived the radical socio-cultural transformation of the city with great displeasure, and those who had actually contributed to this transformation, could not be eased by the peace agreements. On the contrary, dichotomy of these cultural and in terms of civilisation sometimes even extremely different world in the post-war period further deepened. Hundreds of newly incoming villagers were not able to adapt to the new conditions, and the original inhabitants acquired a persistent feeling of rootlessness in their own city as a result of the rural immigration.

\section{Conclusion:}

\section{Is It Possible to Restore the Original Concept of Home in Bosnia and Herzegovina?}

Some authors have discussed the question whether it is at all possible to restore "home" in its original case in the case under scrutiny (Al-Ali, Koser, 2002). Most of the returnees managed to get back their property. This fact, however, did not mean that the claimants renewed their "home" in the broad sense of the word. Even those who did return got accustomed to the previously well-known environment with difficulties.

In connection with the war experience and its destructive consequences, the transformation of local social structures, changes in the character and nature of the settlements and its housebuilding and even the surrounding landscape significantly changed the overall perception of the geographic space and the character of home. Areas that were on the lines of conflicts likewise completely changed as a consequence of war destruction and the subjugation of everything to military tactics. In addition to burnt houses and other buildings and ruined infrastructure, the surrounding forests were cut down for firewood, meadows, fields and orchards were wildly overgrown, sprawled sacred objects were virtually swallowed by bushes. Fear of the danger of mines the same as gloom memories of past horrors of ethnic cleansing effectively deterred potential returnees. Many roads lost their significance because of the new geographical order, other gained importance.

At the same time, however, it would be a mistake to conceptualise "home" only as a spatial term, leaving aside its other dimensions. "Home" represents, due to the fact that it mostly emphasises its spatial attributes, a timeless and unchanging unit. Yet, in the context of the post-war radical transformation of society it is not very suitable. Not only that the aforementioned geographic area, in which the refugees lived, changed, former inhabitants also changed. Refugees transferred elsewhere felt nostalgia not only for their pre-war residence, but also for the kind of life they had led (Jansen, 2006).

If one takes into consideration a more comprehensive concept of "home," then the focus of the International Community to only ensure security and reconstruction assistance to the returnees seems a rather inadequate inceptive for sustainable return. According to Zetter, for instance, a living organism of mutual relations and traditions that reach back into the past forms an integral part of "home" in addition to the physically confined space. In the case of "home," one should not omit the symbolic representation of the inherited status and order (Zetter, 1999). Minority returnees often stated that what they found in their original "home" upon return did not resemble their previous life in any way. V. Lukić and M. Nikitović, for example, who dealt with the demographic and socioeconomic characteristics of refugees from $\mathrm{BiH}$ in Serbia, reached the conclusion that persons older than 60 years of age were the most willing to repatriate (Lukić, Nikitović, 2004). In contrast, younger and more educated refugees, married couples and those who would have to return making use of the so-called minority way of return refused repatriation altogether. The change also contributed to a profound transformation of the original neighbourly relations. Old neighbours were gone; new residents, who had moved here had often a completely different relationship to the area and the place itself. Research has shown that the desire and willingness to return increased with age and conversely decreased with the level of education. Seniors had a certain "advantage" - unlike the economically active people they did not have to deal with and address the burning issue of their own livelihood upon return. For this reason, senior citizens did not have to be discouraged from returning back because of the inadequate (or rather non-existent) job offers.

The initial understanding of "home" was greatly influenced also by new political geography, especially by the newly created entity border separating the Federation of $\mathrm{BiH}$ from the Republika Srpska. The poorly delineated lines from the economic perspective (they often senselessly separated from each other sites pitched to the same central settlement) created a new type of marginal territory in various areas. This fact likewise had a negative impact of the refugee's decision whether to return or not (Chaveneau-Le Brun, 2001); both entities showed and still show (initially strongly) different socio-economic characteristics as well as administrative and legal conditions. Entity lines in many cases even pass through settlements, which is something that 
causes great difficulties and considerable hardship and quite paradoxical situations to local inhabitants. Compared to pre-war life, the returnee had to take into consideration the new geographical spread of the economic networks, distribution of services and especially their availability (the quality of infrastructure).

As has already been stated above, minority return meant at least theoretically a degree of calming in the life of the refugee. The moment of handing over the keys from the reconstructed home draw a line under the period full of uncertainty. However, did the refugees returning back across the entity lines outlined as a result of the above mentioned situation really feel to be back home?

\section{References}

Al-Ali, N. 2001. Transnational or A-National: Bosnian Refugees in the UK and the Netherlands. In: New Approaches to Migration? Transnational Communities and the Transformation of Home, Al-Ali, N., Koser, K. (eds.), Routledge, London-New York, 96117.

Al-Ali, N. 2002. Loss of Status or New Opportunities? Gender Relations and Transnational Ties among Bosnian Refugees. In: The Transnational Family: New European Frontiers and Global Networks, Bryceson, D., VUORELA, U. (eds.), Berg, Oxford, 83-102 pp.

Al-Ali, N., Koser, K. 2002. Transnationalism, International Migration and Home. In: New Approaches to Migration? Transnational Communities and the Transformation of Home, Al-Ali, N., Koser, K. (eds.), Routledge, London-New York, 1-14 pp.

Al-Rasheed, M., 1994. The Myth of Return: Iraqi Arab and Assyrian Refugees in London. Journal of Refugee Studies 7-2-3, 187-206.

Belloni, R. 2007. State Building and International Intervention in Bosnia. Routledge, London-New York, $213 \mathrm{pp}$.

BHAS, 2011. Unemployment in Bosnia and Herzgeovina, http://www.bhas.ba/index.php [1 Mart 2011] (in Bosnian).

Black, R. 2002. Conceptions of "Home" and the Political Geography of Refugee Repatriation: Between Assumption and Contested Reality in Bosnia-Herzegovina. Applied Geography 22, 123-138.

Bošković, A., Gavrilović, D., Perica, V. 2011. Myths, political mythologies and nationalism. In: Political myths in the former Yugoslavia and successor states: a shared narrative, Gavrilović, D., Perica, V. (eds.), Republic of Letters, Dordrecht, 13-19 pp.

Bringa, T. 2009. Being Muslim in the Bosnian Way. Sahinpasic books, Sarajevo-Zagreb, 272 pp. (in Croation)
Cattaruzza, A. 2001Sarajevo: uncertain capitale. Balkanologie 5, 67-78. (in French)

Coughlan, R., Owens-Manley, J. 2006. Bosnian Refugees in America. New Communities. Springer, New York, $196 \mathrm{pp}$.

Čukur, M. 2005. Dilemmas of return - two anthropological case studies. In: Returning Home: An Evaluation of Sida's Integrated Area Programmes in Bosnia and Herzegovina, Čukur, M. (ed.), Sida, Stockholm 47-101 pp.

D’Onofrio, L. 2004. Welcome Home? Minority return in south-eastern Republika srpska. In: Sussex Migration Working Paper 19, Sussex Centre for Migration Research, University of Sussex, http://www. sussex.ac.uk/migration/documents/mwp19.pdf [29 November 2010].

Eastmond, M. 1998. Nationalist Discourses and the Constructions of Differences: Bosnian Muslim Refugees in Sweden. Journal of Refugee Studies 11, 161181.

Eastmond, M. 2006. Transnational Returns and Reconstruction in Post-war Bosnia and Herzegovina. International Migration 44, 141-166.

Faist, T. 2000. Transnationalization in International Migration: Implications for the Study of Citizenship and Culture. Ethnic and Racial Studies 23, 189-19o.

Fischel De Andrade, J., Delaney, N.B. 2001. Minority Return to South-Eastern Bosnia and Herzegovina: A review of the 2000 Return Season. Journal of Refugees Studies 14, 315-330.

Grečić, V. 1990. The Importance of Migrant Worker's and Emigrant's Remittances for the Yugoslav Economy. International Migration 28, 201-213.

Hallergård, C. 1998. Bosnia and Herzegovina: problems and progress in the return process. Forced migration Review 1, 21-23.

Hammond, L. 1999. Examining the Discourse of Repatriation: Towards a More Proactive Theory of Return Migration. In: The End of the refugee cycle? Refugee repatriation and reconstruction, Black, R., Koser, K. (eds.), Berghahn Books, New York, 227$244 \mathrm{pp}$.

Harrell-Bond, B.E. 1988. The sociology of Involontary Migration: An Introduction. Current Sociology 36, $1-6$.

Hasić, T. 2004. Ethnic Conflict and the Right to Return of Limbo Diasporas: Multifaceted Reflections on the Case of BiH. Migracijske i etničke teme. 20, 29-49.

Hockenos, P. 2003. Homeland calling: exile patriotism and the Balkan wars. Cornell University, Ithaca, $289 \mathrm{pp}$.

Huttunen, L. 2005. 'Home' and ethnicity in the context of war. Hesitant diasporas of Bosnian refugees. European Journal of Cultural Studies 8, 177-195. 
Chaveneau-Le Brun, E. 2001. Interentity Boundary Line: New bordes, new country? Balkanologie 5, 79-92. (in French)

IASFM, 2007. International Association for the Study of Forced Migration, http://www.iasfm.org/ [27 May 2007].

ICG, 2002. The Continuing Challenge of Refugee Return in Bosnia and Herzegovina, http://www.crisisgroup.org/ /media/Files/europe/137\%20-\%20The\%20 Continuing\%20Challenge $\% 20$ Of\%2oRefugee $\% 20 R e-$ turn\%2oIn\%2oBosnia.pdf [15 January 2007].

Jakobsen, J. 2011. Bosnia and the Remittances-Institutions-Development Nexus. In: The Bosnian Diaspora. Integration in Transnational Communities, Valenta, M., Ramet, P. R. (eds.), Ashgate, Farnham, 185-206 pp.

Jansen, S. 2006. The Privatisation of Home and Hope: Return, Reforms and the Foreign Intervention in Bosnia-Herzegovina. Dialectical Anthropology 30, 177-1999.

Jansen, S., Löfving S. 2007. Introduction: Movement, violence, and the making of home. Focaal - European Journal of Anthropology 49, 3-14.

Jelavich, B. 1983. History of the Balkans: 2oth Century.Cambridge University Press, Cambridge, 476 pp.

Kolind, T. 2003. Non-ethnic Condemnation in PostWar Stolac. An Ethnographic Case-Study from Bosnia-Herzegovina. In: The Balkans in Focus: Cultural Boundaries in Europe, Tonrquist-Plewa, B., Resic, S. (eds.), Nordic Academic Press, Lund, 121-133 pp.

Kostić, R. 2003. Strategies of livelihood in post-war Bosnia-Herzegovina: a study of the economic predikament of returning home. In: Working $\mathrm{Pa}$ per 4, Legacy of War and Violence project, Göteborg, 35 pp.

Kovačević, D. 2013 Young People from Bosnia And Herzegovina in Norway: Migration, Identity And Ethnicity. Revista Română de Studii Baltice și Nordice/The Romanian Journal for Baltic and Nordic Studies 5, 69-85.

Kovačević, I., Krstić, M. 2011. Between History and Modernity: The Anthropological Study of Migrant Workers in the 21st Century. Issues in Ethnology and Anthropology 6, 969-982. (in Serbian)

Kunz, E. 1988. Exile and Resettlement: Refugee Theory. International Migration Review 1, 42-51.

Lukić, V. 2005. Izbegličke migracije iz Bosne i Hercegovine u Beogradu. Geografski institut "Jovan Cvijić", SANU, Beograd, 130 pp. (in Serbian)

Lukić, V., Nikitović, V. 2004. Refugees from Bosnia and Herzegovina in Serbia: A Study of Refugee Selectivity. International Migration 42, 85-110.

Markotić, A. 1996. Croats in Bosnia and Herzegovina. In: Hrvatski geografski kongres, Zagreb, 221227. (in Croatian)
Marković, P. 2005. Gastarbeiters as the Factor of Modernization in Serbia. Istorija 20. veka 2, 145-163.

Marković, P. 2009. Lost in transmigration? Serbian gastarbeiters between the worlds. Hereticus 4, 7-21. (in Serbian)

MARRI Project, 2005. Legal and actual status of refugees, displaced persons and returnees to Bosnia and Herzegovina. In: Civil society working group for Bosnia and Herzegovina, http://www.lex-ngo. org/dokumenti/access_to_rights_en.pdf [19 September 2012].

MHRR, 2010. Revised Strategy Of Bosnia And Herzegovina. For the Implementation of Annex VII of the Dayton Peace Agreement, www.unhcr.ba/images/stories/Spotlight/annex7strategyfinaleng.pdf [18 February 2010].

Ó Tuathail, G., Dahlman, C. 2004. The Effort to Reverse Ethnic Cleansing in Bosnia -Herzegovina: The Limits of Returns. Eurasian Geography and Economics 45, 439-464.

Ó Tuathail, G., Dahlman, C. 2005. Has Ethnic Cleansing succeeded? Geographies of Minority Return and its Meaning in Bosnia-Herzegovina. In: Dayton - Ten Years After: Conflict Resolution, Co-operation Perspectives, Gosar, A. (ed.), Založba Annales, Koper, 349-366.

OHR, 1995. General Framework Agreement for Peace in Bosnia and Herzegovina. Annex VII. Agreement of refugees and Displaced Persons, http://www.ohr. int/dpa/default.asp?content_id=375 [27 July 2011].

O'Loughlin, J. 2010. Inter-ethnic friendships in postwar Bosnia-Herzegovina: Sociodemographic and place influences. Ethnicities 10, 26-53.

Perica, V. 2009. Nacije i dijaspore: Mit o sakralnom centur i vječnom povratku. In: Mitovi nacionalizma i demokratija, Gavrilović, D., Despotović, L., Perica, V., Šljukić, S., Grafomarketing, Novi Sad, 79-117 pp.

Perica, V. 2011. Ethnic Diaspora as political factor and national myth. In: Political myths in the former Yugoslavia and successor states: a shared narrative, Gavrilović, D., Perica, V. (eds.), Republic of Letters, Dordrecht, 57-65 pp.

Petrin, S. 2002. Refugee return nad state reconstruction: a comparative analysis. In: New Issues in Refugee Research: Evaluation and Policy Analysis Unit, UNHCR, Working Paper 66, 1-23 pp.

Raduški, N. 2011. Refugees from Bosnia and Herzegovina in Serbia: Socio-demographic Characteristics, Status and Prospects. In: The Bosnian Diaspora. Integration in Transnational Communities, Valenta, M., Ramet, P. R. (eds.), Ashgate, Farnham, 123$142 \mathrm{pp}$.

Rosand, E. 1998. The Right to Return Under International Law Following Mass Dislocation: The Bosnia 
Precedent. Michigan Journal of International Law 19, 1092-1139.

Sacco, J. 2007. Safe area Goražde. The War in eastern Bosnia 1992-95. Fantagraphics Books, Seattle, 240 pp.

Stefannson, A. 2004a. Refugee return to Sarajevo and their challenge to contemporary narratives of mobility. In: Coming Home? Refugees, migrants, and those who stayed behind, Long, L., Oxfeld, E. (eds.), University of Pennsylvania Press, Philadelhia, 170$186 \mathrm{pp}$.

Stefannson, A. 2004b. The House War: The Politics, Practice and Meaning of Home in Bosnia and Herzegovina. In: Working paper 10, Göteborg University, http://www.gu.se/digitalAssets/809/809981_ WP1oStefansson.pdf [16 October 2010].

Stefannson, A. 2006. Homes in the Making: Property Restitution, Refugee Return, and Senses of Belonging in a Post-war Bosnian Town. International migration 44, 115-139.

UNDP, 2002. Human Development Report 2002, http:/hdr.undp.org/es/informes/nacional/europa-
ci/bosniaherzegovina/Bosnia_and_Herzegovina_2002_en.pdf [1 July 2008].

UNDP, 2010. Early Warning System, Quarterly Report, http://www.undp.ba/upload/publications/ EWS_EN_final.pdf [12 November 2011].

Valenta, M., Ramet, P. R. (eds.) 2011. The Bosnian Diaspora. Integration in Transnational Communities. Ashgate, Farnham, 356 pp.

Zetter, R. 1999. Reconceptualizing the myth of return: continuity and transition amongst the Greek-Cypriot refugees of 1974. Journal of Refugee Studies 12, 1-22.

Žíla, O. 2013. The Socioeconomic Development of Bosnia and Herzegovina in the Years 1948-1991 and its Impact to the Population Movements of the three Constitutional Nations. Časopis 20. století 5, 47-65. (in Czech)

Žíla, O. 2014. "Returning Home”: The various courses for the repatriation process within Bosnia and Hercegovina (selected case studies). Porta Balkanica 6, 34-49. (in Czech) 